\title{
Investigation and Research on the Current Situation of Erosion Gully in Northeast Semi-arid Region
}

\author{
Shiqian Gao ${ }^{2,3,4,5,{ }^{*}}$ and Yutong Zhao ${ }^{1,2,3,4,5}$ \\ ${ }^{1}$ Institute of Land Engineering and Technology, Shaanxi Provincial Land Engineering Construction Group Co., Ltd.. 710075, Xi'an, \\ China \\ ${ }^{2}$ Shaanxi Provincial Land Engineering Construction Group Co., Ltd. 710075, Xi'an, China \\ ${ }^{3}$ Key Laboratory of Degraded and Unused Land Consolidation Engineering, the Ministry of Natural Resources, 710075, Xi' an, China \\ ${ }^{4}$ Shaanxi Provincial Land Consolidation Engineering Technology Research Center.710075, Xi'an, China \\ ${ }^{5}$ Land Engineering Quality Testing of Shaanxi Land Engineering Construction Group Co., Ltd. Shaanxi, China
}

\begin{abstract}
The occurrence and development of erosion gully will increase the area of soil erosion and continuously erode the cultivated land.The treatment of erosion gully is swing in the black soil region of Northeast China.However, they are all directed at the typical black soil area, while the soil erosion caused by the erosion gully in the semi-arid area of Northeast is less concerned.The study uses a combination of RS and census data.Exploring the number of erosion gully and the status of development, The survey results show that :the number of erosion gully is large, and most of them are developmental erosion gully.If the governance measures are not taken in time, the erosion ditch may continue to develop.
\end{abstract}

Keywords: semi-arid area in northeast, soil erosion, erosion gully

\section{Foreword}

Soil erosion is one of the most important ecological and environmental problems at present. Among them, trench erosion is the most destructive and has become one of the most serious indicators of land degradation. Gully erosion occurs on the earth except in the polar regions, and $85.7 \%$ occurs in agriculture and animal husbandry. On the ground, the quality of the land and the cultivability and area of the arable land are reduced, which seriously threatens the regional agriculture and ecological security. Therefore, trench erosion has always been the focus of research in domestic and foreign academic circles. With the increasingly serious environmental pollution and ecological degradation, the coordinated development of human, ecology and environment has become one of the most popular scientific and social issues in the $21 \mathrm{st}$ century. Dealing with this problem has become the goal of domestic and foreign scholars day and night. With the improvement of the soil erosion control project in the Loess Plateau of Northwest China, the problem of soil erosion in the Northeast has attracted people's attention. Channel erosion is the main form of soil erosion in Northeast China.With the launch of high-precision satellites and the development of high-tech such as UAV telemetry in recent years, the research content of erosion ditch in Northeast my country is also changing with each passing day. The research results show that nearly $90 \%$ of the erosion ditch in the Mangang area of Manchuan in the northeast are unstable erosion ditch, and the development intensity and distribution density of the erosion ditch in the north are significantly higher than those in the southern area. Some people also use high-resolution satellites and make full use of remote sensing technology to explore the identification method of erosion ditch, in order to provide technical means for follow-up research on the monitoring and management of erosion ditch.These studies are all from macroscopic considerations, studying the distribution and development characteristics of erosion ditch, and few people start from the microscopic soil physical properties.According to early research results: About $70 \%$ of the erosion trenches were formed around the 1960s[1],It has a long developmental process After the founding of the People's Republic of China, in order to rapidly develop the economy, large-scale logging was used to make steel. The vegetation coverage on the ground was severely reduced, the ecological environment was severely damaged, and soil erosion was intensified[2,3].Ridge farming along the slope is one of the important reasons for the rapid development of eroded ditches in Northeast China.[4,5]. The concentrated rainstorm period from July to September each year is the high incidence period of farmland erosion gully[610]Erosion ditch is formed under the combined action of multiple external forces such as water flow and gravity. The occurrence and development of eroded gully will not only cause the gully head to advance, the gully bottom to be cut down, and the gully bank to collapse, increase the

\footnotetext{
* Corresponding author: 1129712869@qq.com
} 
runoff intensity, and aggravate the soil erosion in the area[11-18]. It will also destroy the integrity of the land, destroy roads, block traffic, cause great inconvenience to people's lives, and reduce the arable area of crops, resulting in a significant drop in crop yields[19-21], restricting the economic income of residents, and erosion trenches can also fragment intact ecosystems

\section{Overview of the study area}

The semi-arid area of Northeast China mainly manifests in ecological and environmental problems such as low and concentrated annual rainfall, underdeveloped surface water system, thin and barren soil layer, poor vegetation growth environment, and poor site conditions for restoration and reconstruction. It is a typical soil erosion in Northeast my country. Ecologically fragile areas are highly sensitive to the occurrence and development of eroded gully.According to the typical study on the boundary definition of typical soil species and marginal soil species in black soil"People's Republic of China Industry Standard SL190-96 Soil Erosion Classification and Grading Standard"--the definition and description of the black soil area in Northeast China in the second-level division of the national soil erosion type division, as well as the national soil classification map soil types and the three northeastern provinces and four Inner Mongolia A spatial analysis of superimposed administrative boundaries of the Union,And refer to the distribution of vegetation types, precipitation contours, topography and other spatial distribution characteristics to identify the boundary of the sensitive area of the erosion ditch.The research area mainly includes the Fuxin Mongolian Autonomous Region in northwest Liaoning, Baicheng area in northwest Jilin, Chifeng area in Inner Mongolia and Tongliao area in Xing'an League

\section{Research methods}

The investigation on the current situation of eroded gully in semi-arid area is based on the 2013 water census, ArcGIS is used to superimpose the boundary data of key study districts and counties in the semi-arid region of Northeast China with it, and the distribution of erosion ditch and the degree of erosion in this area are obtained by cutting calculation.

\section{Results and analysis}

Data research and field investigation were conducted in the semi-arid area of Northeast China. The statistics of soil erosion area and erosion intensity classification in each region are shown in Table 1.The overall rainfall in this area is small, but the rainfall is concentrated, and the vegetation growth is restricted, resulting in widespread erosion of farmland and barren slopes. The development status and development characteristics of erosion ditch in this area are shown in Table 2. Among them, there are 41,019 erosion ditch over 100 meters in length, with a total length of $33,877,322$ meters and a total area of
$92,092.78$ square hectares, with an average slope drop of $9.46 \%$.

Table 1. Soil erosion and erosion intensity in ecological fragile area of black soil area

\begin{tabular}{|c|c|c|c|c|c|c|c|}
\hline \multirow[b]{2}{*}{$\begin{array}{l}\text { Locat } \\
\text { ion }\end{array}$} & \multirow[b]{2}{*}{$\begin{array}{l}\text { Area } \\
(\mathrm{km} \\
\left.{ }^{2}\right)\end{array}$} & \multicolumn{6}{|c|}{ Each Erosion Intensity Area $\left(\mathrm{km}^{2}\right)$} \\
\hline & & $\begin{array}{c}\text { Sligh } \\
\mathrm{t}\end{array}$ & Mild & $\begin{array}{l}\text { Moder } \\
\text { ate }\end{array}$ & $\begin{array}{l}\text { Stren } \\
\text { gth }\end{array}$ & $\begin{array}{c}\text { Extre } \\
\text { me } \\
\text { Stren } \\
\text { gth }\end{array}$ & $\begin{array}{l}\text { Sev } \\
\text { ere }\end{array}$ \\
\hline $\begin{array}{c}\text { Xing' } \\
\text { an } \\
\text { Leagu } \\
\mathrm{e}\end{array}$ & 20304 & $\begin{array}{c}6693 . \\
59\end{array}$ & $\begin{array}{c}6489 . \\
58\end{array}$ & $\begin{array}{c}3565 . \\
55\end{array}$ & $\begin{array}{c}2668 . \\
39\end{array}$ & $\begin{array}{c}786.5 \\
4\end{array}$ & $\begin{array}{c}100 . \\
36\end{array}$ \\
\hline $\begin{array}{c}\text { Tongl } \\
\text { iao }\end{array}$ & 20313 & $\begin{array}{c}6696 . \\
55\end{array}$ & $\begin{array}{c}6492 . \\
46\end{array}$ & $\begin{array}{c}3567 . \\
13\end{array}$ & $\begin{array}{c}2669 . \\
57\end{array}$ & $\begin{array}{c}786.8 \\
8\end{array}$ & $\begin{array}{c}100 . \\
40\end{array}$ \\
\hline Fuxin & 4552 & $\begin{array}{c}1500 . \\
65\end{array}$ & $\begin{array}{c}1454 . \\
91\end{array}$ & $\begin{array}{c}799.3 \\
7\end{array}$ & $\begin{array}{c}598.2 \\
3\end{array}$ & $\begin{array}{c}176.3 \\
4\end{array}$ & $\begin{array}{c}22.5 \\
0\end{array}$ \\
\hline Total & 45169 & $\begin{array}{c}1489 \\
0.7 \\
\end{array}$ & $\begin{array}{c}1443 \\
6.9\end{array}$ & $\begin{array}{c}7932 . \\
05\end{array}$ & $\begin{array}{c}5936 . \\
20\end{array}$ & $\begin{array}{c}1749 . \\
76\end{array}$ & $\begin{array}{c}223 . \\
26\end{array}$ \\
\hline
\end{tabular}

Table 2. Characteristics of erosion gully in ecological fragile area of black soil area

\begin{tabular}{ccccc}
\hline Location & $\begin{array}{c}\text { Quantity } \\
(\mathrm{n})\end{array}$ & $\begin{array}{c}\text { Length } \\
(\mathrm{m})\end{array}$ & $\begin{array}{c}\text { Area } \\
(\mathrm{hm} 2)\end{array}$ & $\begin{array}{c}\text { Mean } \\
\text { slope } \\
(\%)\end{array}$ \\
\hline $\begin{array}{c}\text { Xing'an } \\
\text { League }\end{array}$ & 29352 & 24186503 & 67959.09 & 10.49 \\
$\begin{array}{c}\text { Tongliao } \\
\text { Fuxin }\end{array}$ & 7815 & 7672509 & 20222.84 & 11.11 \\
Total & 4852 & 2018310 & 3910.85 & 6.78 \\
& & & &
\end{tabular}

The soil in the surveyed area of Xing'an League is complex. There are mainly brown coniferous forest soil and gray forest soil along the altitude gradient, and then gradually transition to dark brown soil and then chestnut soil at the bottom of the mountain; The soil texture in Tongliao City is mainly chestnut soil, and there are also aeolian sandy soil and gray meadow soil in some areas; The soil in Fuxin transitioned from brown soil to loess, mainly leaching cinnamon soil, juvenile forest brown soil, aeolian sandy soil, and meadow soil. Most of the region has a dry climate with poor soil and low soil moisture content. The management of erosion ditch should firstly be based on engineering and technical means, while effectively controlling soil and water loss, providing an environment for vegetation growth and laying a foundation for the subsequent ecological restoration of erosion ditch.

\section{Conclusion}

Erosion ditch is one of the main types of soil erosion in the Northeast semi-arid region. The research results show that the area of eroded ditch in Xing'an League is 67,959 hectares and the length is 29,352 meters, which is much higher than that in Tongliao and Fuxin.And most of them are primary erosion ditch with low erosion intensity. If it is not treated in time, it will inevitably lead to the continuous development of erosion ditch, increase the degree of soil erosion, further reduce the area of cultivated land, and affect the integrity of the land. Therefore, we should pay attention to the problems caused by soil erosion in this area, increase investment in a timely 
manner, strengthen remediation efforts, and control the further expansion of erosion ditch in this area.

\section{Outlook}

Erosion ditch governance is difficult. At present, the governance of erosion ditch is mainly based on engineering, which is divided into slope engineering and ditch engineering. Development ditch is generally chosen as the object of treatment, and there are some treatment measures for large, medium and small erosion ditch, but all of them are mainly gabion valleys. The protection measures at the head of the ditch are not implemented much, and the annular dam is mainly built with mortar and masonry, and no protection measures for falling water have been found, The slope measures are mainly to build horizontal grooves parallel to the contour lines, and plant water conservation plants to achieve the purpose of protecting the hillside from soil erosion.There are not many projects that specifically implement plant measures for ecological restoration of eroded channels.

However, the use of ecological restoration technology to control erosion ditch is the most reasonable model, It is also more difficult.Most of the trenches were built after the gabion valley, and the vegetation restoration relies on natural succession, but the effect is not outstanding at present.Mainly because the plant species is single, poplar trees are planted in places where the siltation at the bottom of the ditch reaches a certain level, and other plants are rarely used.Secondly, the vegetation coverage in these areas is low, and the grasses are not lush. The weeds that grow naturally in the erosion ditch become one of the places for cattle and sheep to graze. Therefore, cattle and sheep are frequently gnawed and trampled, and vegetation succession is slow. The effect is better after building a fence in a certain area. However, most of the eroded ditch in this area are steep and the wild plant seeds have no conditions for attachment. Even without disturbance, the vegetation restoration of the ditch slope is still difficult. Therefore, the ecological restoration of eroded ditch is more difficult.

\section{References}

1. Qin W,Zuo C D,Fan J R,et al.Countermeasures for erosion ditch control in Northeast black soil region[B]. Soil and Water Conservation,2014:37-41.

2. Li Z G,Wang Y S,Liu X C,et al.Census methods and results of erosion trenches in black soil region of Northeast my country[A].Soil and Water Conservation Science in China,2013,11(5):16723007.

3. E J P.Summary report of comprehensive scientific investigation on soil erosion and ecological security in China[J].Beijing: Soil and Water Conservation in China,2008.

4. Fan H M,Cai Q G,Cui M.Study on vertical zoning of soil erosion in black soil mangang area in Northeast China[J].Chinese Journal of Agricultural Engineering,2005,21(6):8-11.
5. ZHao Y M,Jiang H T, Wang S J.Study on relative soil and water conservation benefit of different topographic ridge slope in Northeast black soil region[J].Soil and Water Conservation Research,2015,21(5):28-34.

6. Yan B X,Yang Y H,Liu X T,et al.Status and evolution trend of soil erosion in black soil region of Northeast China[J].Soil and Water Conservation in China,2008(12):26-30.

7. Gu G H,Wang Y S,ZHong Y F,et al.Research on the development characteristics of erosion gulch in mangang area manchuan Northeast China[J].Soil and Water Conservation Research,2015,22(02):47$51+57$

8. Yu P X,ZHou X,Liu S H,et al.Feature extraction and identification of remote sensing images of erosion gully in black soil region of Northeast China[J].Acta Remote Sensing,2018,22(04):611-620.

9. Wang D A,Liu G,Wang X Y,et al.Difference analysis of the composition of eroded sediment particles measured by laser method and straw method in black soil area in Northeast China[J].Soil and Water Conservation Science in China,2016,14(01):114-122.

10. Castillo C,Gómez J A. A century of gully erosion research: Urgency, complexity and study approaches[J]. Earth-Science Reviews,2016:300-319.

11. Meng L Q,Research on gully erosion mechanism and control mode in black soil region of Northeast China[D].Chinese Academy of Agricultural Sciences, 2009.

12. ZHao P,Peng S L,ZHang J W,Ecosystem fragility and degraded ecosystems[J].Journal of Tropical and Subtropical Botany,1998,6(3):179-186.

13. CHai Z P,Liang Z,Wang X M,et al.The effect of continuous cropping on soil physical properties of cotton fields[J].China Agricultural Science Bulletin,,2008(08):192-195.

14. Wang ZH M,Liu J X,Gao Y,et al.Classification of erosion trenches based on remote sensing and GIS[B].Northeast Water Conservancy and Hydropower,2016,5:40-43.

15. Wang Z P,Cai J P,ZHang Z K,et al.The dynamic changes of the status quo of soil and water loss in Liaoning Province and the countermeasures for its prevention and control[A].Soil and Water Conservation Science and Technology Information 2002,5:32-36.

16. Bian F,ZHeng F L,Xu X M,et al.Comparison of slope erosion process between along-slope ridge farming and no-ridge farming in northeastern black soil region $[\mathrm{J}]$. Soil and Water Conservation Bulletin,2016,36(1):10-17.

17. ZHang Y L,Wang Z M,Gao Y,et al.Investigation and research on the development trend of erosion gully in typical black soil area[J]. Soil and water conservation in China,2015,(10):63-69.

18. ZHong $\mathrm{Y}$ F,Benefit analysis of comprehensive management of soil and water conservation in small 
watersheds in black soil region of Northeast China[D].Jilin University,2011.

19. ZHeng G X,Li X H,Ren L H,et al.Research and evaluation of soil and water conservation forest models in the rocky hilly area of western Liaoning[B].Soil and water conservation application technology,2007,5:7-9.

20. Lan J T,Fan H M,CHai Y,et al.Study on soil erosion characteristics of different land use types in low soil and rocky mountainous areas in western Liaoning[B].China Soil and Water Conservation SWCC, 2009, 8: 8-11.

21. Fan F,ZHang Y L,ZHu Z L,et al.Soil characteristics and remediation strategies of natural grassland in Tongliao City[A].Journal of Inner Mongolia University for Nationalities, 2002, 17(2): 130-135. 